Original Article

\title{
Antifungal activity of 2-chloro- $N$-phenylacetamide: a new molecule with fungicidal and antibiofilm activity against fluconazole-resistant Candida spp.
}

\author{
Atividade antifúngica de 2-cloro- $N$-fenilacetamida: uma nova molécula com atividade \\ fungicida e anti-biofilme contra Candida spp. resistentes a fluconazol
}

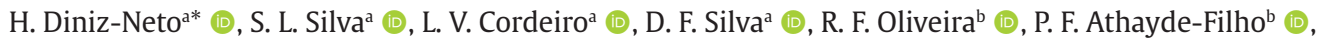 \\ A. A. Oliveira-Filho ${ }^{c}$ (D) F. Q. S. Guerra ${ }^{a}$ (D) and E. O. Lima ${ }^{a}$ (D) \\ aUniversidade Federal da Paraíba - UFPB, Department of Pharmaceutical Sciences - DCF, João Pessoa, PB, Brasil \\ bUniversidade Federal da Paraíba - UFPB, Department of Chemistry - DQ, João Pessoa, PB, Brasil \\ 'Universidade Federal de Campina Grande - UFCG, Rural Health and Technology Center - CTSR, Patos, PB, Brasil
}

\begin{abstract}
In the current context of emerging drug-resistant fungal pathogens such as Candida albicans and Candida parapsilosis, discovery of new antifungal agents is an urgent matter. This research aimed to evaluate the antifungal potential of 2-chloro- $N$-phenylacetamide against fluconazole-resistant clinical strains of $C$. albicans and $C$. parapsilosis. The antifungal activity of 2-chloro- $\mathrm{N}$-phenylacetamide was evaluated in vitro by the determination of the minimum inhibitory concentration (MIC), minimum fungicidal concentration (MFC), inhibition of biofilm formation and its rupture, sorbitol and ergosterol assays, and association between this molecule and common antifungal drugs, amphotericin B and fluconazole. The test product inhibited all strains of $C$. albicans and C. parapsilosis, with a MIC ranging from 128 to $256 \mu \mathrm{g} \cdot \mathrm{mL}^{-1}$, and a MFC of $512-1,024 \mu \mathrm{g} \cdot \mathrm{mL}^{-1}$. It also inhibited up to $92 \%$ of biofilm formation and rupture of up to $87 \%$ of preformed biofilm. 2 -chloro- $N$-phenylacetamide did not promote antifungal activity through binding to cellular membrane ergosterol nor it damages the fungal cell wall. Antagonism was observed when combining this substance with amphotericin B and fluconazole. The substance exhibited significant antifungal activity by inhibiting both planktonic cells and biofilm of fluconazole-resistant strains. Its combination with other antifungals should be avoided and its mechanism of action remains to be established.
\end{abstract}

Keywords: antifungal drug resistance, antifungal susceptibility, Candida albicans, Candida parapsilosis, invasive candidiasis.

\begin{abstract}
Resumo
No atual contexto de patógenos fúngicos resistentes emergentes tais como Candida albicans e Candida parapsilosis, a descoberta de novos agentes antifúngicos é uma questão urgente. Esta pesquisa teve como objetivo avaliar o potencial antifúngico da 2 -cloro- $N$-fenilacetamida contra cepas clínicas de $C$. albicans e $C$. parapsilosis resistentes a fluconazol. A atividade antifúngica da substância foi avaliada in vitro através da determinação da concentração inibitória mínima (CIM), concentração fungicida mínima (CFM), ruptura e inibição da formação de biofilme, ensaios de sorbitol e ergosterol, e associação entre esta molécula e antifúngicos comuns, anfotericina B e fluconazol. $\mathrm{O}$ produto teste inibiu todas as cepas de C. albicans e C. parapsilosis, com uma CIM variando de 128 a $256 \mu$ g.mL $\mathrm{mL}^{-1}$, e uma CFM de 512-1,024 $\mu \mathrm{g} \cdot \mathrm{mL}^{-1}$. Também inibiu até $92 \%$ da formação de biofilme e causou a ruptura de até $87 \%$ de biofilme pré-formado. A 2-cloro- $N$-fenilacetamida não promoveu atividade antifúngica pela ligação ao ergosterol da membrana celular fúngica, tampouco danificou a parede celular. Antagonismo foi observado ao combinar esta substância com anfotericina B e fluconazol. A substância exibiu atividade antifúngica significativa ao inibir tanto as células planctônicas quanto o biofilme das cepas resistentes ao fluconazol. Sua combinação com outros antifúngicos deve ser evitada e seu mecanismo de ação deve ser estabelecido.
\end{abstract}

Palavras-chave: resistência antifúngica, susceptibilidade antifúngica, Candida albicans, Candida parapsilosis, candidíase invasiva.

*e-mail: hermes.dn@hotmail.com

Received: August 5, 2021 - Accepted: January 19, 2022

This is an Open Access article distributed under the terms of the Creative Commons Attribution License, which permits unrestricted use, distribution, and reproduction in any medium, provided the original work is properly cited. 


\section{Introduction}

Fungal infections are a serious global problem, accounting for more than 1.6 million deaths annually (Almeida et al., 2019). Infections caused by Candida spp. are the most frequent, accounting for $80 \%$ of cases of systemic fungal infections (Alvarez-Moreno et al., 2018; Gamaletsou et al., 2018). Candidiasis usually manifests as superficial cutaneous-mucosal infections, but can also progress to the disseminated form, candidemia (Lamoth et al., 2018).

Although $C$. albicans remains the most common fungal pathogen worldwide, a significant increase in infections caused by non-albicans species is reported in the last decade (Jain et al., 2017; Lamoth et al., 2018; Vieira et al., 2018). Of such species, $C$. parapsilosis has already been ranked as the second most frequent cause of candidemia in some countries of Southern Europe, Africa, North America and, notably, in a great portion of South America, especially in neonates, transplant recipients and patients with other malignancies such as cancer (Silva et al., 2012; Sun et al., 2019; Tóth et al., 2019; Zupančič et al., 2018).

Therapeutic failure in the treatment of certain fungal strains has been described in several clinical, epidemiological, pharmacological and case reports studies. This is due to the occurrence of antifungal resistance, which is a well-known threat and is continuously increasing worldwide (Aldardeer et al., 2020; Asadzadeh et al., 2017; Fisher et al., 2018; Hassanmoghadam et al., 2019; Reinhardt et al., 2020).

The difficulty of treatment, length of stay and associated costs, toxicity and scarcity of antifungal drugs, mortality rates, and antifungal resistance aggravates the challenge in tackling these infections and brings the urge to develop new antifungals in order to overcome this threat (Chatelon et al., 2019; Kneale et al., 2016; Olaechea et al., 2004).

An organic synthesis is a valuable tool in developing new pharmacologically active compounds. Thus, new and old substances are being studied to this goal, expanding the options of available products with antifungal potential.

The 2-chloro- $N$-phenylacetamide with a molecular formula of $\mathrm{C}_{8} \mathrm{H}_{8} \mathrm{ClNO}$ (Figure 1) is a molecule extensively used in organic synthesis to obtain a wide range of substances, producing other pharmacologically active molecules with antimicrobial, anti-inflammatory and analgesic effect (Gouda et al., 2018; Yadav et al., 2018).

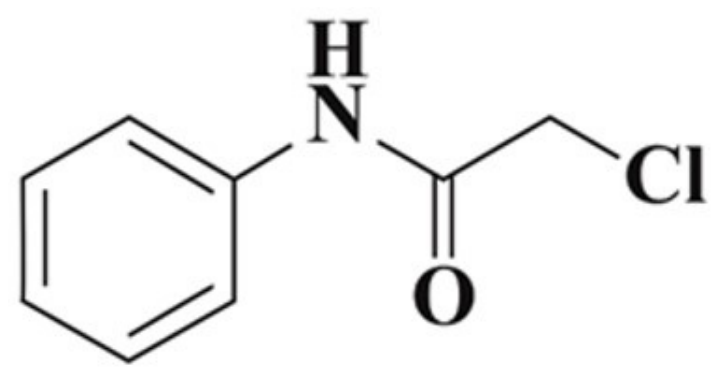

Figure 1. The chemical structure of 2-chloro- $N$-phenylacetamide.
Since the antifungal potential of this molecule was not fully investigated, the present study aims to thoroughly analyze its antifungal properties, as well as the resistance profile of the selected strains. Hence, the antifungal susceptibility of the strains was assessed through microdilution technique to determine the test product minimum inhibitory and minimum fungicidal concentrations, and later, studies of the microbial growth curve, biofilm inhibition and rupture potential, mechanism of action and association study with amphotericin B and fluconazole were conducted.

\section{Materials and Methods}

\subsection{Test substance and antifungal drugs}

The test substance 2-chloro- $N$-phenylacetamide was synthesized and provided by the Laboratory of Bioenergy and Organic Synthesis, of the Federal University of Paraíba, João Pessoa, PB, Brazil (Peixoto et al., 2016). The antifungals employed in the trials were: fluconazole, voriconazole, and amphotericin B. These substances were purchased from Sigma-Aldrich ${ }^{\circledR}$ (São Paulo, SP, Brazil). The 2-chloro- $N$ phenylacetamide and the antifungal drugs were solubilized in $5 \%$ dimethyl-sulfoxide (DMSO) and $2 \%$ Tween 80 , to obtain emulsions in the concentrations necessary for use in the tests (Cleeland and Squires, 1991; Hood et al., 2003; Pereira et al., 2015).

\subsection{Culture media}

The culture medium Sabouraud Dextrose Agar (SDA) (Difco Laboratories, Detroit, MI, USA) was used for the maintenance of the strains. The liquid culture medium Roswell Park Memorial Institute (RPMI)-1640-L-glutamine (without sodium bicarbonate)(Sigma-Aldrich®, São Paulo, SP, Brazil) was used for the antifungal assays. Both culture media were prepared according to the manufacturer's instructions.

\subsection{Microorganisms}

In the experiments, standard strains of Candida albicans ATCC 76485 (American Type Culture Collection) and Candida parapsilosis ATCC 22019 were used, as well as clinical strains of C. albicans: LM-117, LM-516, LM-587, LM-616, LM-699; and C. parapsilosis (sensu lato): LM-439, LM-546, LM-5770, LM-55117. The susceptibility profiles of these strains to amphotericin B, voriconazole and fluconazole, according to the CLSI criteria are presented in Table 1.

The fungal strains were provided by the Antibacterial and Antifungal Activity Research Laboratory of the Federal University of Paraíba, João Pessoa, PB, Brazil. The microorganisms were kept in SDA at $4{ }^{\circ} \mathrm{C}$ until the realization of the tests. Prior to each experiment, the cells were reactivated on SDA agar plates For inoculum preparation, the colonies of microorganisms were suspended in $0.85 \%$ sterile $\mathrm{NaCl}$ solution and adjusted to the 0.5 scale of McFarland standard (Cleeland and Squires, 1991; CLSI, 2008; Hadacek and Greger, 2000). 
Table 1. Susceptibility profile of the tested strains.

\begin{tabular}{|c|c|c|c|c|}
\hline & \multirow{2}{*}{ Strains } & AmB & Vrc & Flc \\
\hline & & \multicolumn{3}{|c|}{$\operatorname{MIC}\left(\mu \mathrm{g} \cdot \mathrm{mL}^{-1}\right)$} \\
\hline \multirow[t]{6}{*}{ C. albicans } & ATCC 76485 & $0.25(\mathrm{~S})$ & $0.125(S)$ & $32(\mathrm{R})$ \\
\hline & LM-117 & $0.25(S)$ & $0.062(S)$ & $08(\mathrm{R})$ \\
\hline & LM-516 & $0.25(\mathrm{~S})$ & $0.125(S)$ & $64(\mathrm{R})$ \\
\hline & LM-587 & $0.25(\mathrm{~S})$ & $0.125(\mathrm{~S})$ & $16(\mathrm{R})$ \\
\hline & LM-616 & $0.25(S)$ & $0.062(S)$ & $04(\mathrm{I})$ \\
\hline & LM-699 & $0.25(\mathrm{~S})$ & $0.062(\mathrm{~S})$ & $08(\mathrm{R})$ \\
\hline \multirow[t]{6}{*}{ C. parapsilosis } & ATCC 22019 & $0.25(\mathrm{~S})$ & $0.125(S)$ & $16(\mathrm{R})$ \\
\hline & LM-439 & $0.50(\mathrm{~S})$ & $0.50(\mathrm{I})$ & $32(\mathrm{R})$ \\
\hline & LM-546 & $0.50(S)$ & $0.50(\mathrm{I})$ & $16(\mathrm{R})$ \\
\hline & LM-689 & $0.25(\mathrm{~S})$ & $0.50(\mathrm{I})$ & $64(\mathrm{R})$ \\
\hline & LM-5770 & $0.50(S)$ & $0.25(\mathrm{I})$ & $32(\mathrm{R})$ \\
\hline & LM-55117 & $0.25(\mathrm{~S})$ & $0.25(\mathrm{I})$ & $08(R)$ \\
\hline
\end{tabular}

Legend: AmB = Amphotericin B; Vrc = Voriconazole; Flc = Fluconazole; $\mathrm{S}=$ Susceptible; I = Intermediate; R = Resistant (CLSI, 2017, p. 60).

\subsection{Minimum inhibitory concentration}

The Minimum Inhibitory Concentration (MIC) of 2-chloro-phenylacetamide at the starting concentration of $1,024 \mu \mathrm{g} . \mathrm{mL}^{-1}$ against the strains of $C$. albicans and C. parapsilosis was determined through the broth microdilution technique in a 96-well microplate for cellular culture (Eloff, 1998; Hadacek and Greger, 2000; CLSI, 2008). At the same time, the medium sterility control (wells containing only the culture medium), microbial viability control (wells containing the culture medium with the fungal inoculum) and interference of the solubilizing agents (5\% DMSO and 2\% Tween 80 ), as well as a control with amphotericin B (at a starting concentration of $8 \mu \mathrm{g} \cdot \mathrm{mL}^{-1}$ ) were performed. The plates were incubated at $35 \pm 2{ }^{\circ} \mathrm{C}$ for $24 \mathrm{~h}$ for reading. The experiment was conducted in triplicate. The MIC was defined as the lowest concentration of the products in which there was visible inhibition of fungal growth in the wells when compared to its controls. The results were expressed as the arithmetic mean of the MIC's obtained in the three experiments.

\subsection{Minimum fungicide concentration}

After reading the MIC, $10 \mu \mathrm{L}$ aliquots of the supernatant of the wells where complete inhibition of fungal growth was observed (MIC, MICx2 and MICx4) in the microdilution plates were transferred to the wells of a new microplate containing $100 \mu \mathrm{L}$ of RPMI broth, where they were incubated by $24 \mathrm{~h}$ at $35 \pm 2{ }^{\circ} \mathrm{C}$. The experiment was conducted in triplicate. The MFC was considered as the lowest concentration of the product in which there was no fungal growth in the culture medium. The results were expressed as the arithmetic mean of the MFC's obtained in the three experiments (Ncube et al., 2008; Salie et al., 1996; Silva et al., 2020).

\subsection{Microbial growth curve}

For the following tests, one ATCC strain and one clinical strain of each species which showed high MIC results were randomly selected and used. The MIC assay results were confirmed by verifying the interference of different product concentrations (MIC, MICx2 and MICx4) on the microbial growth curve in a $24 \mathrm{~h}$ period. Following the same procedure in the MIC assay, the plates were incubated for 24 hours at $35 \pm 2{ }^{\circ} \mathrm{C}$ in a microplate reader (BIOTEK $^{\mathrm{TM}} \mathrm{EON}^{\mathrm{TM}}$ ) and absorbance values were read at $530 \mathrm{~nm}$ every four hours. The experiment was carried out in triplicate. The growth curves were constructed by plotting the absorbance recorded by the microplate reader as a function of time (hours) with the statistical software GraphPad Prism (version 6.0 to Windows, San Diego, CA - USA) (Schacht et al., 2013; Stevenson et al., 2016).

\subsection{Inhibition of biofilm formation}

The ability of Candida species to form biofilm is an aggravating factor in the control of this pathogen, since it facilitates its dissemination. In this way, a product that is able to prevent the installation of this structure on various surfaces becomes a valuable resource in the prevention of these fungal infections (Lohse et al., 2020).

To assess the effect of 2-chloro- $N$-phenylacetamide in the inhibition of biofilm formation, $10 \mu \mathrm{L}$ of fungal inoculum of C. albicans (ATCC-76485, 117, 516, 587 and 616) and C. parapsilosis (ATCC-22019, 439, 689 and 5770) were incubated by $48 \mathrm{~h}$ at $35 \pm 2{ }^{\circ} \mathrm{C}$ in $100 \mu \mathrm{L}$ of RPMI broth at different concentrations of 2-chloro- $\mathrm{N}$-phenylacetamide (MICx4, MICx2, MIC, MIC/2, MIC/4). Then, the wells were emptied, washed with sterile distilled water for the removal of unadhered cells and separated for drying at room temperature. After drying, the contents fixed on the walls of the wells was dyed with $140 \mu \mathrm{L}$ of violet crystal 
solution at $1 \%$ (NEWPROV®) for 40 minutes. After disposal and washing of excess dye and drying, $140 \mu \mathrm{L}$ of absolute ethanol was added (RIOQUÍMICA®) for 30 minutes.

The quantification of cells fixed and dyed in the well walls was performed in microplate spectrophotometer (Multiskan GO) at $590 \mathrm{~nm}$. At the same time, negative control was performed with only the culture medium and fungal inoculum. All analyses were performed in triplicate and the results were expressed as the arithmetic mean of the absorption values obtained, being plotted in graphs with the statistical software GraphPadPrism (version 6.0 for Windows, San Diego, CA - USA). The percentage of inhibition of biofilm formation was calculated using the following formula: \% inhibition of biofilm formation $=100-\left[\left(\mathrm{ABS}_{590}\right.\right.$ test $/ \mathrm{ABS}_{590}$ control $\left.) \mathrm{x} 100\right]$.

\subsection{Rupture of preformed biofilm}

In addition to preventing the formation of biofilm, a product that is capable of penetrating and damaging its already formed structure also acquires great bioactive relevance, since an already established biofilm confers great resistance to the fungus against external aggressions such as antifungal drugs (Tsui et al., 2016).

To observe if the product is capable of damaging the mature biofilm, $10 \mu \mathrm{L}$ of fungal inoculum of $C$. albicans (ATCC-76485, 117, 516, 587 and 616) and C. parapsilosis (ATCC-22019, 439, 689 and 5770) were incubated for $48 \mathrm{~h}$ at $35 \pm 2{ }^{\circ} \mathrm{C}$ in $100 \mu \mathrm{L}$ of RPMI broth for the biofilm formation. After disposal of the contents of the wells, $100 \mu \mathrm{L}$ of RPMI broth containing different concentrations of 2-chloro- $\mathrm{N}$ phenylacetamide (MICx4, MICx2, MIC, MIC/2, MIC/4) were added and incubated again for $48 \mathrm{~h}$ at $35 \pm 2{ }^{\circ} \mathrm{C}$.

Then, similarly as described previously in the inhibition of biofilm formation, the steps for dyeing the fixed cells and reading in microplate spectrophotometer (Multiskan $\mathrm{GO})$ at $590 \mathrm{~nm}$ were conducted. In parallel, the negative control was performed where the culture medium, without the test substance, was added to the wells with formed biofilm. All analyses were performed in triplicate and the results were expressed as the arithmetic mean of the absorption values obtained, being plotted in graphs with the statistical software GraphPadPrism (version 6.0 for Windows, San Diego, CA - USA). The percentage of biofilm rupture was calculated using the following formula: \% of biofilm rupture $=100-\left[\left(\mathrm{ABS}_{590}\right.\right.$ test $/ \mathrm{ABS}_{590}$ control $\left.) \mathrm{x} 100\right]$ (Rajasekharan et al., 2017).

\subsection{Effect on fungal cell wall}

In order to observe whether 2-chloro-N-phenylacetamide causes damage to the fungal cell wall, the MIC of the product was evaluated in the presence and absence of an osmotic stabilizer, sorbitol. If a product somehow affects the fungal cell wall, it will damage the cell when in the absence of sorbitol, on the other hand, yeast growth will occur in the presence of this osmotic protector.

The determination of the product's MIC in the presence of sorbitol was performed by the microdilution method, as described previously, where microorganisms were exposed to different concentrations of the test product in a medium containing sorbitol $(0.8 \mathrm{M})$. In parallel, controls were carried out with caspofungin as well as to assure sterility of the medium and microbial viability (Frost et al., 1995; Zacchino, 2001).

\subsection{Ergosterol binding assay}

Still considered a gold standard in the treatment of invasive candidiasis, amphotericin B exerts its effects by interacting directly with the ergosterol found in the cellular membrane, damaging the fungal cell. Since the presence of exogenous ergosterol in the culture medium decreases the binding of antifungals to the membrane ergosterol, the MIC of substances such as amphotericin $\mathrm{B}$ and other products that act through this mechanism is expected to increase, since a higher concentration of the antifungal agent will be required to interact with its molecular target (Valgus, 2003).

The determination of the product's MIC against $C$. albicans and $C$. parapsilosis strains was performed by the microdilution method, as described previously, where microorganisms were exposed to different concentrations of the test products in a medium with ergosterol (400 $\mu$ g. $\left.\mathrm{mL}^{-1}\right)$. Finally, the same procedure was performed with amphotericin B as control, an antifungal agent with known affinity and action on membrane ergosterol, as well as the controls of sterility and microbial viability (Escalante et al., 2008).

\subsection{Association study - checkboard method}

To assess the effects of the association between the 2-chloro- $N$-phenylacetamide and two standard antifungal drugs: fluconazole and amphotericin $B$; against the $C$. albicans and $C$. parapsilosis strains, the checkerboard method was employed. Initially, $100 \mu \mathrm{L}$ of the culture medium was added to the wells of a sterile 96-wells microplate with a "U" shaped bottom. At the same time, dilutions of the test products: 2 -chloro- $N$-phenylacetamide, fluconazole and amphotericin B were prepared in tubes yielding concentrations higher and lower than its MICs (MICx8, MICx4, MICx2, MIC, MIC $\div 2$, MIC $\div 4$ and MIC $\div 8$ ). Then, $50 \mu \mathrm{L}$ of 2 -chloro- $N$-phenylacetamide in the various concentrations was added to $50 \mu \mathrm{L}$ of amphotericin B or fluconazole in each concentration in different microplates. In order to obtain different combinations between the concentrations, the substances were added in different directions in the microplate (acetamide added horizontally, and amphotericin B or fluconazole added vertically). Finally, $20 \mu \mathrm{L}$ of the fungal suspension was added in all the wells. The assay was performed in triplicate, and the microplates were incubated for $24-48 \mathrm{~h}$ at $35 \pm 2{ }^{\circ} \mathrm{C}$.

The fractional inhibitory concentration index (FICI) was calculated using the following equation: $\mathrm{FICI}=\mathrm{FIC}_{\mathrm{A}}+\mathrm{FIC}_{\mathrm{B}}$ $\left(\mathrm{FIC}_{\mathrm{A}}=\right.$ Fractional inhibitory concentration of 2-chloro- $\mathrm{N}$ phenylacetamide; FIC $_{B}=$ Fractional inhibitory concentration of amphotericin $\mathrm{B}$ or fluconazole). The $\mathrm{FIC}_{A}$ is calculated by the combined $\mathrm{MIC}_{A}$ /isolated $\mathrm{MIC}_{A}$ ratio, while the $\mathrm{FIC}_{B}$ is calculated by the combined $\mathrm{MIC}_{B}$ /isolated $\mathrm{MIC}_{B}$ ratio. The index is interpreted as follows: synergism ( $\mathrm{FICI} \leq 0.5)$, indifference $(0.5<\mathrm{ICIF} \leq 4)$ and antagonism (ICIF > 4.0) (Odds, 2003; Shin, 2003; Silva et al., 2020). 


\subsection{Statistical analysis}

The data were analyzed by the Two-way Analysis of Variance (ANOVA) with the Bonferroni post hoc test, using the GraphPadPrism software (version 6.0 for Windows, San Diego, CA, USA). The data were considered significant when $P<0.05$.

\section{Results}

\subsection{Minimum inhibitory concentration and minimum fungicidal concentration assays}

The 2-chloro- $N$-phenylacetamide antifungal profile was evaluated through MIC and MFC determinations. The results are presented in Table 2. The molecule presented inhibitory activity against all tested strains, with an MIC ranging from 128 to $256 \mu \mathrm{g} \cdot \mathrm{mL}^{-1}$. Against the C. albicans strains, the substance exhibited an MIC of $128 \mu \mathrm{g} \cdot \mathrm{mL}^{-1}$ for 2 ( $\approx 33 \%)$ strains and $256 \mu \mathrm{g} \cdot \mathrm{mL}^{-1}$ for the other $4(\approx 67 \%)$ strains. For $C$. parapsilosis, the product exhibited an MIC of $128 \mu \mathrm{g} \cdot \mathrm{mL}^{-1}$ for 3 (50\%) strains, and $256 \mu \mathrm{g} \cdot \mathrm{mL}^{-1}$ for the other 3 strains.

The molecule presented an MFC ranging between 512 and $1,024 \mu \mathrm{g} . \mathrm{mL}^{-1}$ for the tested yeasts. Against C. albicans strains, the substance exhibited an MFC of $512 \mu \mathrm{g} . \mathrm{mL}^{-1}$ for 2 (33\%) strains, and 1,024 $\mu \mathrm{g} \cdot \mathrm{mL}^{-1}$ for another $3(50 \%)$ strains. For $C$. parapsilosis strains, the product exhibited an MFC of 1,024 $\mu \mathrm{g} \cdot \mathrm{mL}^{-1}$ for 3 (50\%) strains.

In relation to the microdilution assay control groups, no fungal growth was observed in the control test containing only culture medium. Abundant fungal growth however was observed in the control test containing only culture medium and fungal inoculum, attesting to the viability of the strains. The same was observed with the solvent
(5\% DMSO and $2 \%$ Tween 80 ) controls, indicating that the products did not interfere with the results.

The MFC:MIC ratio and the classification in which a substance can be considered fungicidal if its MFC:MIC $\leq 4$, or fungistatic if its MFC:MIC $>4$ indicated that 2-chloro-Nphenylacetamide (for 8 (67\%) of the strains tested) presents fungicidal activity (MFC:MIC $\leq 4$ ) (Siddiqui et al., 2013).

\subsection{Microbial growth curves}

Being exposed to differing concentrations of 2-chloro$\mathrm{N}$-phenylacetamide, the yeast growth curves were also observed at different time intervals. The results are shown in the Figures 2 and 3.

The microbial growth curves shown in the figures above reveal that 2 -chloro- $N$-phenylacetamide presents inhibitory activity against strains of $C$. albicans, after 4 hours of exposure with an effect directly proportional to its concentration. For $C$. parapsilosis, no statistical difference was observed for inhibitory effects at the different concentrations tested. Thus, for this species, the test product did not reveal concentration proportional activity.

\subsection{Effect on fungal biofilms}

The biofilm formation assay results are presented in Figures 4 and 5. Rupture percentages for already formed biofilm are presented in Figures 6 and 7.

According to the data obtained, we observed that 2-chloro- $N$-phenylacetamide inhibits biofilm formation (for both of the fungal species tested) in a concentrationdependent manner, being also able to inhibit $50 \%$ of biofilm formation when at sub-inhibitory concentrations (MIC/4).

Although there were no significant differences between species for inhibition rates at normal and supra-inhibitory concentrations (MIC, MICx2 and MICx4); at sub-inhibitory concentrations, $C$. parapsilosis strains continued to form

Table 2. Minimum Inhibitory Concentration (MIC) and Minimum Fungicidal Concentration (MFC) ( $\mu$ g.mL $\mathrm{mL}^{-1}$ ) of 2-chloro- $N$-phenylacetamide against strains of Candida albicans and Candida parapsilosis.

\begin{tabular}{|c|c|c|c|c|c|c|}
\hline \multirow{2}{*}{ Strains } & \multicolumn{3}{|c|}{ 2-chloro-N-phenylacetamide } & \multirow{2}{*}{ SC } & \multirow{2}{*}{ VC } & \multirow{2}{*}{$\mathbf{S}$} \\
\hline & MIC & MFC & MFC/MIC & & & \\
\hline C. albicans ATCC 76485 & 128 & $\geq 2,048$ & ND (Fungistatic) & - & + & + \\
\hline C. albicans LM-117 & 256 & 1,024 & 4 (Fungicide) & - & + & + \\
\hline C. albicans LM-516 & 256 & 1,024 & 4 (Fungicide) & - & + & + \\
\hline C. albicans LM-587 & 256 & 1,024 & 4 (Fungicide) & - & + & + \\
\hline C. albicans LM-616 & 256 & 512 & 2 (Fungicide) & - & + & + \\
\hline C. albicans LM-699 & 128 & 512 & 4 (Fungicide) & - & + & + \\
\hline C. parapsilosis ATCC 22019 & 128 & $\geq 2,048$ & ND (Fungistatic) & - & + & + \\
\hline C. parapsilosis LM-439 & 256 & 1,024 & 4 (Fungicide) & - & + & + \\
\hline C. parapsilosis LM-546 & 256 & 1,024 & 4 (Fungicide) & - & + & + \\
\hline C. parapsilosis LM-689 & 256 & 1,024 & 4 (Fungicide) & - & + & + \\
\hline C. parapsilosis LM-5770 & 128 & $\geq 2,048$ & ND (Fungistatic) & - & + & + \\
\hline C. parapsilosis LM-55117 & 128 & $\geq 2,048$ & ND (Fungistatic) & - & + & + \\
\hline
\end{tabular}

Legend: ND = Not determined; SC = sterility control; VC = viability control; S = Solvent's control; - = Absence of microbial growth; + = Presence of microbial growth. 
$\mathbf{a}$

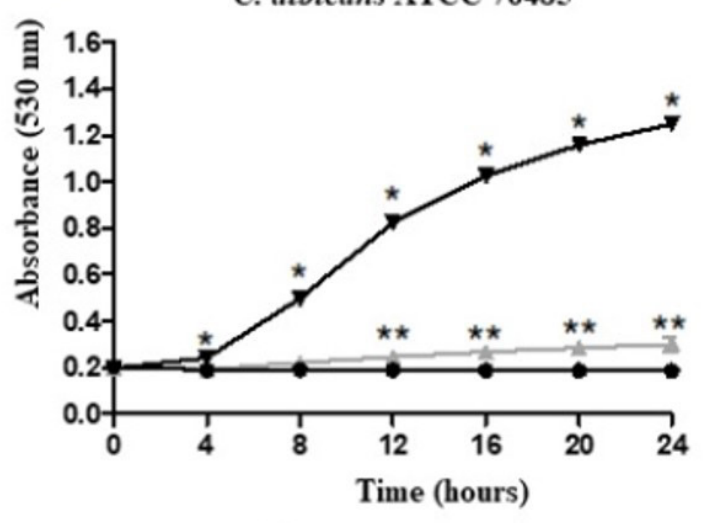

Control $\multimap 2$ CINPA MICx4 b

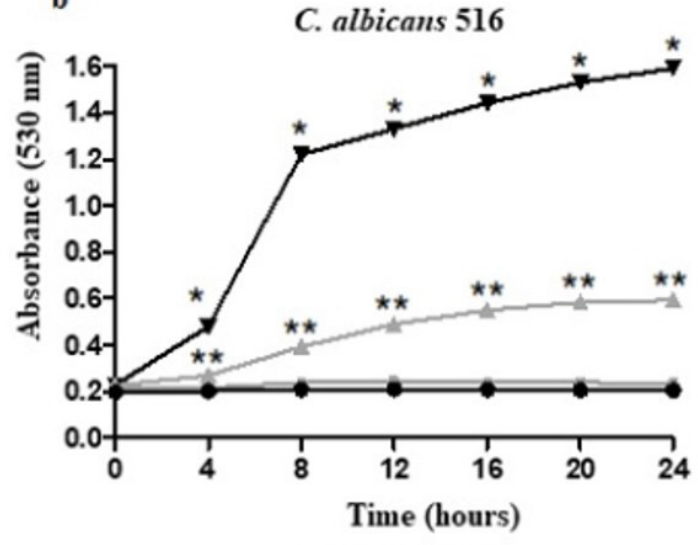

2CINPA MICx2 $₫$ 2CINPA MIC

Figure 2. (a) microbial growth curve of C. albicans ATCC 76485 during a $24 \mathrm{~h}$ period; (b) microbial growth curve of $C$. albicans LM-516, during a $24 \mathrm{~h}$ period; 2CINPA, 2-chloro- $N$-phenylacetamide. *Statistical difference between the concentration and control groups $(p<0.05) ;{ }^{* *}$ Statistical difference between the concentration groups $(P<0.05)$.

a

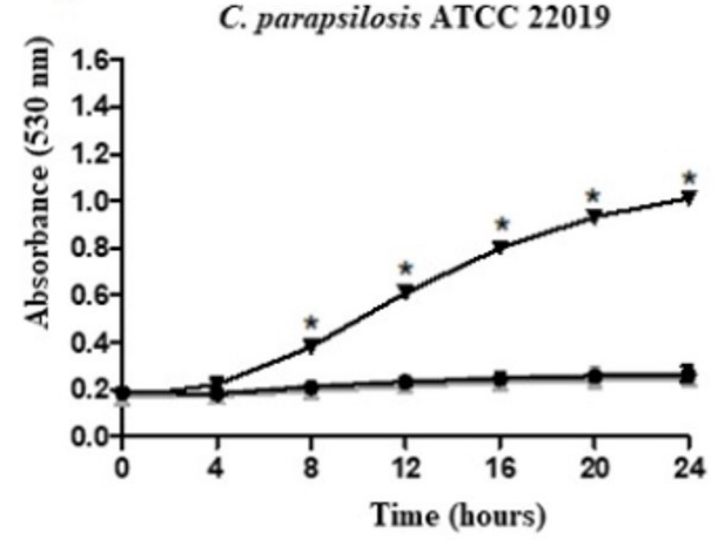

b

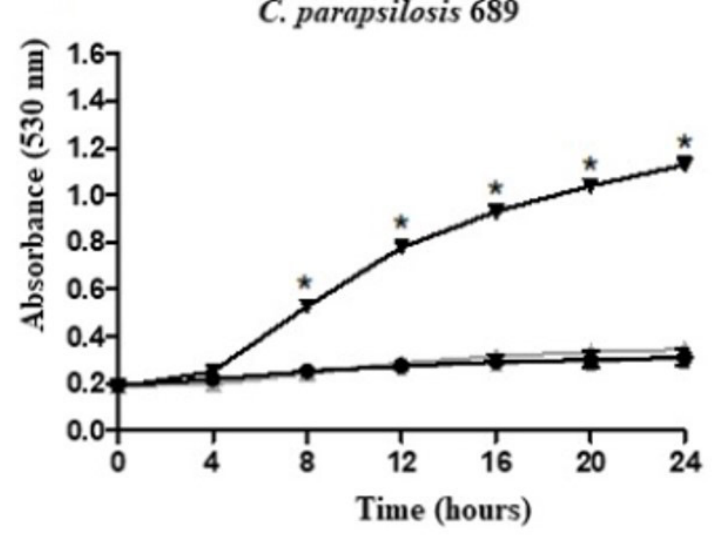

\section{Control $\nleftarrow 2$ CINPA MICx $4-2$ CINPA MICx $2 \multimap 2$ CINPA MIC}

Figure 3. (a) Microbial growth curve of $C$. parapsilosis ATCC 22019 during a 24 h period; (b) Microbial growth curve of $C$. parapsilosis LM-689, during a $24 \mathrm{~h}$ period; 2CINPA, 2-chloro- $N$-phenylacetamide. *Statistical difference between the concentration and control groups $(P<0.05)$.

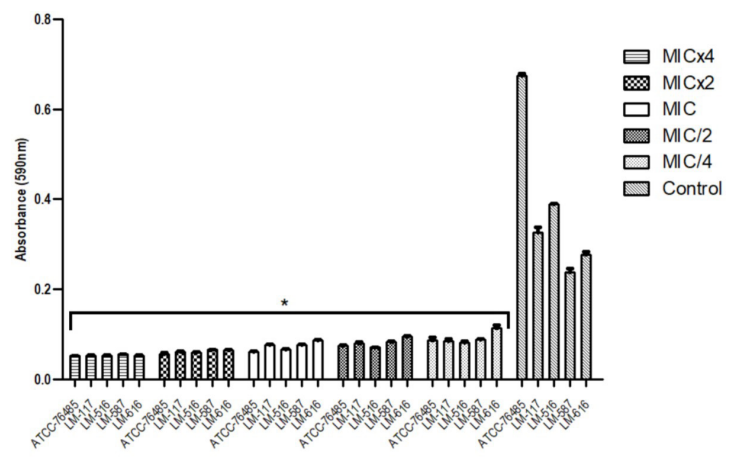

Figure 4. Biofilm formation of $C$. albicans strains exposed to different concentrations of 2 -chloro- $N$-phenylacetamide. ${ }^{*} P<0.05$ compared to the control group.

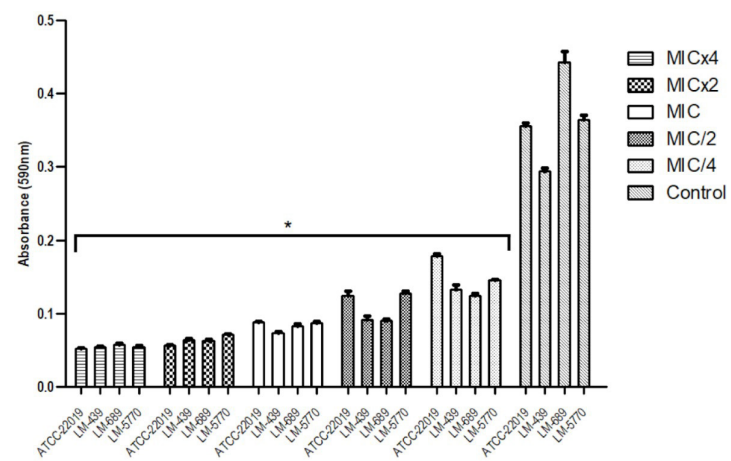

Figure 5. Biofilm formation of $C$. parapsilosis strains exposed to different concentrations of 2 -chloro- $N$-phenylacetamide. ${ }^{*} P<0.05$ compared to the control group. 
greater amounts of biofilm; with respective differences of approximately $6 \%$ and $13 \%$ for $\mathrm{MIC} / 2$ and $\mathrm{MIC} / 4$ ). However, even at the lowest concentrations tested, 2-chloro- $\mathrm{N}$ phenylacetamide was able to inhibit biofilm formation by $50 \%$ as compared to the control group. At higher concentrations, the substance inhibited biofilm formation by $76 \%$ to $92 \%$.

Significant rates of (already formed) biofilm rupture for all strains in all of the tested 2-chloro- $N$-phenylacetamide concentrations, were demonstrated (with the exception of $C$. albicans strain 587; being below $<50 \%$, and only in sub-inhibitory concentrations) (Figure 6). The highest rupture rates (between $67 \%$ and $87 \%$ ) were observed for

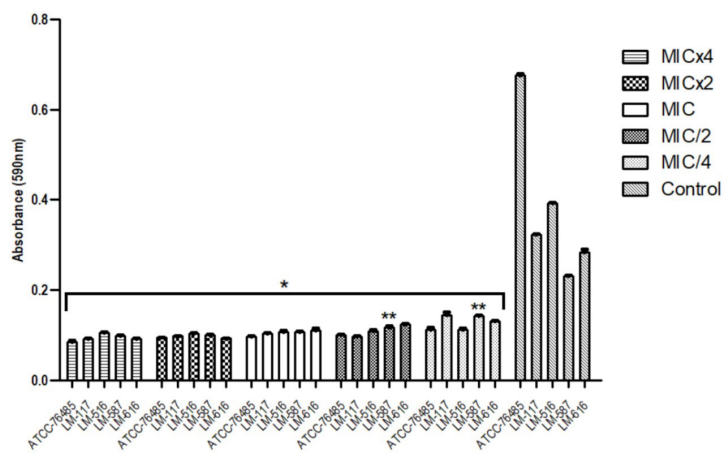

Figure 6. Rupture of $C$. albicans mature biofilm after exposure to different concentrations of 2-chloro- $\mathrm{N}$-phenylacetamide. ${ }^{*} P<0.05$ compared to the control group. ${ }^{* *}$ Rupture less than $50 \%$ compared to control.

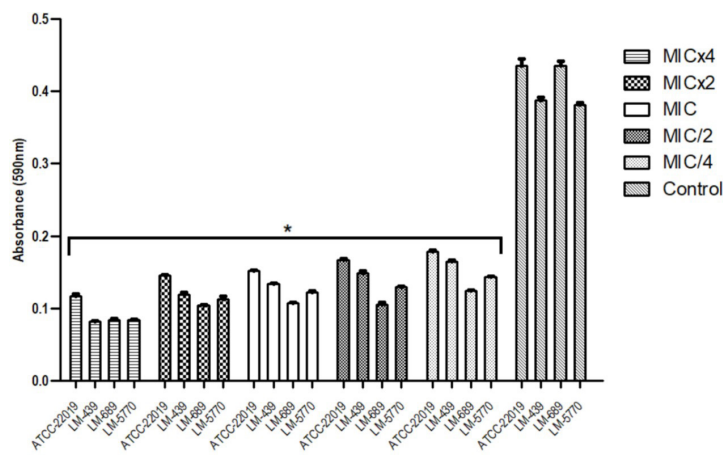

Figure 7. Rupture of $C$. parapsilosis mature biofilm after exposure to different concentrations of 2 -chloro- $N$-phenylacetamide. ${ }^{*} P<0.05$ compared to the control group. the highest substance concentrations, and there were no significant differences between already formed biofilm rupture rates (between species) when tested at the same concentrations.

\subsection{Investigation of mechanism of action through sorbitol and ergosterol assays}

The effects on the fungal cell wall (sorbitol assay) and for binding to membrane ergosterol (ergosterol assay) were investigated as possible mechanisms of action. The results are presented in Tables 3 and 4.

The MIC of 2-chloro- $N$-phenylacetamide remained unchanged both in the absence and in the presence of ergosterol, unlike amphotericin B, whose MIC increased 32 times when exposed to exogenous ergosterol. The same occurred in the sorbitol assay, where the MIC of 2-chloro$\mathrm{N}$-phenylacetamide was unchanged both in the absence and in the presence of sorbitol and only the control with caspofungin presented an MIC increase.

\subsection{Association study}

The results of the 2-chloro- $N$-phenylacetamide association assay with amphotericin B and subsequently with fluconazole are shown in Table 5.

Antagonism $(\mathrm{FICI} \geq 4)$ was observed for all strains tested in both of the 2-chloro- $N$-phenylacetamide antifungal associations. The inhibitory concentrations of the combined compounds were significantly higher than the inhibitory concentrations of the isolated products.

\section{Discussion}

The choice of 2-chloro- $N$-phenylacetamide resulted from observation of previous screening studies carried out by Aschale (2012); Katke et al. (2011); and Patel and Shaikh (2011), in which they observed antimicrobial activity, especially against planktonic strains of $C$. albicans. Yet their results needed further elucidation, since only one strain was used. Thus, in the present study, the number of planktonic strains (C. albicans and C. parapsilosis) used was increased, with specific fluconazole resistance profiles, observing the molecule's activities against the biofilms produced by these species for the first time.

The MIC and MFC results together with the microbial growth curves reveal that 2-chloro- $N$-phenylacetamide presents inhibitory activity against strains of $C$. albicans,

Table 3. Minimum Inhibitory Concentration $\left(\mu \mathrm{g} \cdot \mathrm{mL}^{-1}\right)$ of 2-chloro- $N$-phenylacetamide and Amphotericin B against $C$. albicans and $C$. parapsilosis in the absence and presence of ergosterol $400 \mu \mathrm{g} . \mathrm{mL}^{-1}$.

\begin{tabular}{cccccc}
\hline \multirow{2}{*}{ Strains } & \multicolumn{2}{c}{ 2-chloro- $N$-phenylacetamide } & & \multicolumn{2}{c}{ Amphotericin B } \\
\cline { 2 - 3 } \cline { 5 - 6 } & -Ergosterol & +Ergosterol & & -Ergosterol & +Ergosterol \\
\hline C. albicans ATCC 76485 & 128 & 128 & & 0.25 & 8 \\
C. albicans LM-516 & 256 & 256 & & 0.25 & 8 \\
C. parapsilosis ATCC & 128 & 128 & & 0.25 & 8 \\
22019 & & 256 & & 0.25 & 8 \\
C. parapsilosis LM-689 & 256 & 256 & & \\
\hline
\end{tabular}


Table 4. Minimum Inhibitory Concentration $\left(\mu \mathrm{g} \cdot \mathrm{mL}^{-1}\right)$ of 2-chloro- $N$-phenylacetamide and caspofungin against $C$. albicans and $C$. parapsilosis in the absence and presence of Sorbitol 0.8M.

\begin{tabular}{cccccc}
\hline \multirow{2}{*}{ Strains } & \multicolumn{2}{c}{ 2-chloro- $N$-phenylacetamide } & & \multicolumn{2}{c}{ Caspofungin } \\
\cline { 2 - 3 } \cline { 5 - 6 } & -Sorbitol & +Sorbitol & & -Sorbitol & +Sorbitol \\
\hline C. albicans ATCC 76485 & 128 & 128 & 0.5 & 4 \\
C. albicans LM-516 & 256 & 256 & & & 32 \\
C. parapsilosis ATCC 22019 & 128 & 128 & & 0.062 & 0.25 \\
C. parapsilosis LM-689 & 256 & 256 & & 0.062 & 0.25 \\
\hline
\end{tabular}

Table 5. Determination of Fractional Inhibitory Concentration Index (FICI) of the association between 2-chloro- $N$-phenylacetamide with amphotericin B and fluconazole on strains of Candida albicans and Candida parapsilosis.

\begin{tabular}{ccccccc}
\hline Strains & FIC $_{\mathbf{A}}$ & FIC $_{\mathbf{B}}$ & FICI (+FIc) & FIC $_{\mathbf{A}}$ & FIC $_{\mathbf{B}}$ & FICI (+AmB) \\
\hline C. albicans ATCC 76485 & 2 & 2 & $4(\mathrm{~A})$ & 2 & 2 & $4(\mathrm{~A})$ \\
C. albicans LM-516 & 2 & 2 & $4(\mathrm{~A})$ & 2 & 2 & $4(\mathrm{~A})$ \\
C. parapsilosis ATCC 22019 & 4 & 2 & $6(\mathrm{~A})$ & 2 & 2 & $4(\mathrm{~A})$ \\
C. parapsilosis LM-689 & 2 & 2 & $4(\mathrm{~A})$ & 2 & 2 & $4(\mathrm{~A})$ \\
\hline
\end{tabular}

Legend: Flc = Fluconazole; $\mathrm{AmB}=$ Amphotericin $\mathrm{B} ; \mathrm{A}=$ Antagonism.

after 4 hours of exposure with an effect directly proportional to its concentration. For C. parapsilosis, no statistical difference was observed for inhibitory effects at the different concentrations tested. Thus, for this species, the test product did not reveal concentration proportional activity.

Fungal cell adhesion and subsequent production of extracellular matrix is a major obstacle to the treatment of fungal infections. The protection provided to the fungal colony by mature biofilms makes treatment strategies that were previously effective obsolete, and new strategies which include higher concentrations (of active principle), and new drug associations are needed. For these reasons, substances such as 2-chloro-N-phenylacetamide, which are able to not only prevent biofilms from installing, but also capable of damaging the structure of an already formed biofilm, are promising agents for fungal infection control (Lohse et al., 2020; Nett, 2014; Nett and Andes, 2020; Tsui et al., 2016).

This is the first time that the anti-biofilm potential of 2-chloro- $N$-phenylacetamide has been explored against clinically relevant Candida species, further increasing the antifungal value of the molecule. Together with the other data of this work in its entirety, further study and research to investigate the full pharmacological potential of this substance and its possible derivatives is warranted.

The data from the present study indicate that 2-chloro$N$-phenylacetamide does not act through binding to membrane ergosterol, nor does it damage the fungal cell wall. These findings are relevant because they show that the substance does not act on these two traditional pharmacological targets, and complementary studies must be carried out to investigate its mechanism of action and to elucidate the way in which this substance exerts its antifungal effect.

The findings in the present study suggest that the addition of 2-chloro- $N$-phenylacetamide to antifungal agents such as azoles and polyenes should be avoided, since the performance of both molecules will be impaired, which may aggravate the fungal infection.

Antagonism between two drugs can compromise anti-infection therapy's success, since a decrease in the effective concentration of available bioactive molecules will compromise the desired effect against the pathogen. It is worth mentioning that any decision to combine two or more drugs must be supported by at least in vitro tests demonstrating the results of the association on the pathogen in question (Stein et al., 2016).

\section{Conclusions}

At the tested concentrations, 2-chloro-Nphenylacetamide presented both antifungal activity against strains of fluconazole resistant $C$. albicans and $C$. parapsilosis, and disruption and inhibition of fungal biofilm formation. The substance did not exert antifungal activity through two traditionally analyzed pathways, whether binding to ergosterol at the cell membrane or damaging the fungal cell wall. The test product demonstrated antagonism when in association with amphotericin B and fluconazole, an undesirable characteristic which restricts its use as a possible therapeutic adjuvant against fungal infections. Research regarding the exact mechanism of antifungal action is still required to fully understand this molecule potential. 


\section{Acknowledgements}

This project was financed by the Coordination for the Improvement of Higher Education Personnel (CAPES), concession number: 88882.347055/2019-01; and the National Council for Scientific and Technological Development (CNPq), concession number: 302519/20122. The authors wish to thank for the support provided by the Federal University of Paraíba (UFPB) and the Brazilian funding agencies: CAPES, CNPq.

\section{References}

ALDARDEER, N.F., ALBAR, H., AL-ATTAS, M., ELDALI, A., QUTUB, M., HASSANIEN, A. and ALRADDADI, B., 2020. Antifungal resistance in patients with Candidaemia: a retrospective cohort study. BMC Infectious Diseases, vol. 20, no. 1, pp. 55. http://dx.doi. org/10.1186/s12879-019-4710-z. PMid:31952505.

ALMEIDA, F., RODRIGUES, M.L. and COELHO, C., 2019. The still underestimated problem of fungal diseases worldwide. Frontiers in Microbiology, vol. 10, pp. 214. http://dx.doi.org/10.3389/ fmicb.2019.00214. PMid:30809213.

ALVAREZ-MORENO, C.A., CORTES, J.A. and DENNING, D.W., 2018. Burden of fungal infections in Colombia. Journal of Fungi, vol. 4, no. 2, pp. 41. http://dx.doi.org/10.3390/jof4020041. PMid:29561795.

ASADZADEH, M., AHMAD, S., AL-SWEIH, N. and KHAN, Z., 2017. Epidemiology and molecular basis of resistance to fluconazole among clinical Candida parapsilosis isolates in Kuwait. Microbial Drug Resistance, vol. 23, no. 8, pp. 966-972. http://dx.doi. org/10.1089/mdr.2016.0336. PMid:28353392.

ASCHALE, M., 2012. Synthesis and antimicrobial evaluation of some novel substituted 2-chloroacetanilides. International Journal of Chemtech Research, vol. 4, pp. 1437-1441.

CHATELON, J., CORTEGIANI, A., HAMMAD, E., CASSIR, N. and LEONE, M., 2019. Choosing the right antifungal agent in ICU patients. Advances in Therapy, vol. 36, no. 12, pp. 3308. http://dx.doi. org/10.1007/s12325-019-01115-0. PMid:31617055.

CLEELAND, R. and SQUIRES, E., 1991. Evaluation of new antimicrobials in vitro and in experimental animal infections. Antibiotics in Laboratory Medicine, vol. 3, pp. 739-787.

CLINICAL AND LABORATORY STANDARDS INSTITUTE - CLSI, 2008. Reference method for broth dilution antifungal susceptibility testing of yeasts; approved standard. Wayne. CLSI document, no. M27-A3, Suppl. S (3).

CLINICAL AND LABORATORY STANDARDS INSTITUTE - CLSI, 2017. Performance standards for antifungal susceptibility testing of yeasts. Wayne. CLSI supplement, no. M60.

ELOFF, J.N., 1998. A sensitive and quick microplate method to determine the minimal inhibitory concentration of plant extracts for bacteria. Planta Medica, vol. 64, no. 8, pp. 711-713. http://dx.doi.org/10.1055/s-2006-957563. PMid:9933989.

ESCALANTE, A., GATTUSO, M., PÉREZ, P. and ZACCHINO, S., 2008. Evidence for the mechanism of action of the antifungal phytolaccoside B isolated from Phytolacca tetramera Hauman. Journal of Natural Products, vol. 71, no. 10, pp. 1720-1725. http:// dx.doi.org/10.1021/np070660i. PMid:18816139.

FISHER, M.C., HAWKINS, N.J., SANGLARD, D. and GURR, S.J., 2018. Worldwide emergence of resistance to antifungal drugs challenges human health and food security. Science, vol. 360 , no. 6390, pp. 739-742. http://dx.doi.org/10.1126/science. aap7999. PMid:29773744.
FROST, D.J., BRANDT, K.D., CUGIER, D. and GOLDMAN, R., 1995. A whole-cell Candida albicans assay for the detection of inhibitors towards fungal cell wall synthesis and assembly. The Journal of Antibiotics, vol. 48, no. 4, pp. 306-310. http://dx.doi.org/10.7164/ antibiotics.48.306. PMid:7775267.

GAMALETSOU, M.N., WALSH, T.J. and SIPSAS, N.V., 2018. Invasive fungal infections in patients with hematological malignancies: emergence of resistant pathogens and new antifungal therapies. Turkish Journal of Haematology : Official Journal of Turkish Society of Haematology, vol. 35, no. 1, pp. 1-11. http://dx.doi. org/10.4274/tjh.2018.0007. PMid:29391334.

GOUDA, A.M., ABDELAZEEM, A.H., ABDALLA, A.N. and AHMED, M., 2018. Pyrrolizine-5-carboxamides: exploring the impact of various substituents on the anti-inflammatory and anticancer activities. Acta Pharmaceutica, vol. 68, no. 3, pp. 251-273. http:// dx.doi.org/10.2478/acph-2018-0026. PMid:31259695.

HADACEK, F. and GREGER, H., 2000. Testing of antifungal natural products: methodologies, comparability of results and assay choice. Phytochemical Analysis, vol. 11, no. 3, pp. 137-147. http:// dx.doi.org/10.1002/(SICI)1099-1565(200005/06)11:3<137::AIDPCA514>3.0.CO;2-I.

HASSANMOGHADAM, F., SHOKOHI, T., HEDAYATI, M.T., ASLANI, N., HAGHANI, I., NABILI, M., LOTFALI, E. and MOAZENI, M., 2019. High prevalence of itraconazole resistance among Candida parapsilosis isolated from Iran. Current Medical Mycology, vol. 5, no. 3, pp. 43-46. http://dx.doi.org/10.18502/cmm.5.3.1746. PMid:31850396.

HOOD, J.R., WILKINSON, J.M. and CAVANAGH, H.M., 2003. Evaluation of common antibacterial screening methods utilized in essential oil research. The Journal of Essential Oil Research, vol. 15, no. 6, pp. 428-433. http://dx.doi.org/10.1080/10412905.2003.9698631.

JAIN, A., RAWAT, S.K. and RAI, A., 2017. Rising incidence of nonalbicans Candida and changing susceptibility pattern of bloodstream Candida Isolates in neonates. Journal of Clinical and Diagnostic Research, vol. 11, no. 11. http://dx.doi.org/10.7860/ JCDR/2017/29492.10804.

KATKE, S., AMRUTKAR, S., BHOR, R. and KHAIRNAR, M., 2011. Synthesis of biologically active 2-chloro-N-alkyl/aryl acetamide derivatives. International Journal of Pharmaceutical Sciences and Research, vol. 2, no. 7, pp. 148-156.

KNEALE, M., BARTHOLOMEW, J.S., DAVIES, E. and DENNING, D.W., 2016. Global access to antifungal therapy and its variable cost. The Journal of Antimicrobial Chemotherapy, vol. 71, no. 12, pp. 35993606. http://dx.doi.org/10.1093/jac/dkw325. PMid:27516477.

LAMOTH, F., LOCKHART, S.R., BERKOW, E.L. and CALANDRA, T., 2018. Changes in the epidemiological landscape of invasive candidiasis. The Journal of Antimicrobial Chemotherapy, vol. 73, suppl. 1, pp. i4-i13. http://dx.doi.org/10.1093/jac/dkx444. PMid:29304207.

LOHSE, M.B., GULATI, M., CRAIK, C.S., JOHNSON, A.D. and NOBILE, C.J., 2020. Combination of antifungal drugs and protease inhibitors prevent Candida albicans biofilm formation and disrupt mature biofilms. bioRxiv, vol. 11, pp. 1027. http://dx.doi.org/10.3389/ fmicb.2020.01027. PMid:32523574.

NCUBE, N., AFOLAYAN, A. and OKOH, A., 2008. Assessment techniques of antimicrobial properties of natural compounds of plant origin: current methods and future trends. African Journal of Biotechnology, vol. 7, no. 12, pp. 1797-1806. http:// dx.doi.org/10.5897/AJB07.613.

NETT, J.E. and ANDES, D.R., 2020. Contributions of the biofilm matrix to Candida pathogenesis. Journal of Fungi, vol. 6, no. 1, pp. 21. http://dx.doi.org/10.3390/jof6010021. PMid:32028622. 
NETT, J.E., 2014. Future directions for anti-biofilm therapeutics targeting Candida. Expert Review of Anti-Infective Therapy, vol. 12, no. 3, pp. 375-382. http://dx.doi.org/10.1586/14787210.20 14.885838. PMid:24506174

ODDS, F.C., 2003. Synergy, antagonism, and what the chequerboard puts between them. The Journal of Antimicrobial Chemotherapy, vol. 52, no. 1, pp. 1. http://dx.doi.org/10.1093/jac/dkg301. PMid:12805255.

OLAECHEA, P.M., PALOMAR, M., LEÓN-GIL, C., ÁLVAREZ-LERMA, F., JORDÁ, R., NOLLA-SALAS, J. and LEÓN-REGIDOR, M.A., 2004. Economic Impact of Candida Colonization and Candida infection in the critically Ill patient. European Journal of Clinical Microbiology E Infectious Diseases, vol. 23, no. 4, pp. 323-330. http://dx.doi.org/10.1007/s10096-004-1104-x. PMid:15024623.

PATEL, N.B. and SHAIKH, A.R., 2011. Synthesis of new 1, 3-oxazolyl7-chloroquinazolin-4 $(3 \mathrm{H})$ ones and evaluation of their antimicrobial activities. Acta Poloniae Pharmaceutica vol. 68, no. 2, pp. 223-230. PMid:21485295.

PEIXOTO, I.N., SOUZA, H.D., LIRA, B.F., SILVA, D.F., LIMA, E.O., BARBOSA-FILHO, J.M. and ATHAYDE-FILHO, P.F., 2016. Synthesis and antifungal activity against Candida strains of mesoionic system derived from 1, 3-thyazolium-5-thiolate. Journal of the Brazilian Chemical Society, vol. 27, no. 10, pp. 1807-1813.

PEREIRA, F.O., MENDES, J.M., LIMA, I.O., MOTA, K.S.L., OLIVEIRA, W.A. and LIMA, E.O., 2015. Antifungal activity of geraniol and citronellol, two monoterpenes alcohols, against Trichophyton rubrum involves inhibition of ergosterol biosynthesis. Pharmaceutical Biology, vol. 53, no. 2, pp. 228-234. http:// dx.doi.org/10.3109/13880209.2014.913299. PMid:25414073.

RAJASEKHARAN, S.K., RAMESH, S., SATISH, A.S. and LEE, J., 2017. Antibiofilm and anti- $\beta$-lactamase activities of burdock root extract and chlorogenic acid against Klebsiella pneumoniae. Journal of Microbiology and Biotechnology, vol. 27, no. 3, pp. 542551. http://dx.doi.org/10.4014/jmb.1609.09043. PMid:27974734.

REINHARDT, L.C., NASCENTE, P.S., RIBEIRO, J.S., GUIMARÃES, V.B.S., ETGES, A. and LUND, R.G., 2020. Sensitivity to antifungals by Candida spp samples isolated from cases of chronic atrophic candidiasis (CAC). Brazilian Journal of Biology $=$ Revista Brasileira de Biologia, vol. 80, no. 2, pp. 266-272. http://dx.doi. org/10.1590/1519-6984.190454. PMid:31291399.

SALIE, F., EAGLES, P.F.K. and LENG, H.M.J., 1996. Preliminary antimicrobial screening of four South African Asteraceae species. Journal of Ethnopharmacology, vol. 52, no. 1, pp. 27-33. http:// dx.doi.org/10.1016/0378-8741(96)01381-5. PMid:8733116.

SCHACHT, V., NEUMANN, L., SANDHI, S., CHEN, L., HENNING, T., KLAR, P., THEOPHEL, K., SCHNELL, S. and BUNGE, M., 2013. Effects of silver nanoparticles on microbial growth dynamics. Journal of Applied Microbiology, vol. 114, no. 1, pp. 25-35. http:// dx.doi.org/10.1111/jam.12000. PMid:22943489.

SHIN, S., 2003. Anti-Aspergillus activities of plant essential oils and their combination effects with ketoconazole or amphotericin b. Archives of Pharmacal Research, vol. 26, no. 5, pp. 389-393. http://dx.doi.org/10.1007/BF02976696. PMid:12785735.

SIDDIQUI, Z.N., FAROOQ F., MUSTHAFA, T.N.M., AHMAD, A. and KHAN, A.U., 2013. Synthesis, characterization and antimicrobial evaluation of novel halopyrazole derivatives. Journal of Saudi Chemical Society, vol. 17, no. 2, pp. 237-243. http://dx.doi. org/10.1016/j.jscs.2011.03.016

SILVA, D., DINIZ-NETO, H., CORDEIRO, L., SILVA-NETA, M., SILVA, S., ANDRADE-JÚNIOR, F., LEITE, M., NÓBREGA, J., MORAIS, M.,
SOUZA, J., ROSA, L., MELO, T., SOUZA, H., SOUSA, A., RODRIGUES, G., OLIVEIRA-FILHO, A. and LIMA, E., 2020. (R)-(+)- $\beta$-Citronellol and $(S)-(-)-\beta$-Citronellol in Combination with Amphotericin B against Candida Spp. International Journal of Molecular Sciences, vol. 21, no. 5, pp. 1785. http://dx.doi.org/10.3390/ijms21051785. PMid:32150884.

SILVA, S., NEGRI, M., HENRIQUES, M., OLIVEIRA, R., WILLIAMS, D.W. and AZEREDO, J., 2012. Candida glabrata, Candida parapsilosis and Candida tropicalis: biology, epidemiology, pathogenicity and antifungal resistance. FEMS Microbiology Reviews, vol. 36, no. 2, pp. 288-305. http://dx.doi.org/10.1111/j.1574-6976.2011.00278.x. PMid:21569057.

STEIN, C., MAKAREWICZ, O., FORSTNER, C., WEIS, S., HAGEL, S., LÖFFLER, B. and PLETZ, M., 2016. Should daptomycin-rifampin combinations for MSSA/MRSA isolates be avoided because of antagonism? Infection, vol. 44, no. 4, pp. 499-504. http://dx.doi. org/10.1007/s15010-016-0874-2. PMid:26797915.

STEVENSON, K., MCVEY, A.F., CLARK, I.B., SWAIN, P.S. and PILIZOTA, T., 2016. General calibration of microbial growth in microplate readers. Scientific Reports, vol. 6, no. 1, pp. 38828. http://dx.doi. org/10.1038/srep38828. PMid:27958314.

SUN, M., CHEN, C., XIAO, W., CHANG, Y., LIU, C. and XU, Q., 2019. Increase in Candida parapsilosis candidemia in cancer patients. Mediterranean Journal of Hematology and Infectious Diseases, vol. 11, no. 1, pp. e2019012. http://dx.doi.org/10.4084/ mjhid.2019.012. PMid:30671218.

TÓTH, R., NOSEK, J., MORA-MONTES, H.M., GABALDON, T., BLISS, J.M., NOSANCHUK, J.D., TURNER, S.A., BUTLER, G., VÁGVÖLGYI, C. and GÁCSER, A., 2019. Candida parapsilosis: from genes to the bedside. Clinical Microbiology Reviews, vol. 32, no. 2, pp. e00111-e00118. http://dx.doi.org/10.1128/CMR.00111-18. PMid:30814115.

TSUI, C., KONG, E.F., and JABRA-RIZK, M.A., 2016. Pathogenesis of Candida albicans biofilm. FEMS Pathogens and Disease, vol. 74, no. 4, pp. ftw018.

VALGUS, J.M., 2003. What's new in antifungals? Current Infectious Disease Reports, vol. 5, no. 1, pp. 16-21. http://dx.doi.org/10.1007/ s11908-003-0060-4. PMid:12525286.

VIEIRA, J.N., FEIJÓ, A.M., BUENO, M.E., GONÇALVES, C.L., LUND, R.G., MENDES, J.F., VILLARREAL, J.P.V., VILLELA, M.M. and NASCENTE, P.S., 2018. Evaluation of the frequency of Candida spp. in hospitalized and non-hospitalized subjects. Brazilian Journal of Biology $=$ Revista Brasileira de Biologia, vol. 78, no. 4, pp. 644-652. http://dx.doi.org/10.1590/1519-6984.169623. PMid:29451605.

YADAV, S., LIM, S.M., RAMASAMY, K., VASUDEVAN, M., SHAH, S.A.A., MATHUR, A. and NARASIMHAN, B., 2018. Synthesis and evaluation of antimicrobial, antitubercular and anticancer activities of 2-(1-benzoyl-1 H-benzo [d] imidazol-2-ylthio)$\mathrm{N}$-substituted acetamides. Chemistry Central Journal, vol. 12, no. 1, pp. 66. http://dx.doi.org/10.1186/s13065-018-0432-3. PMid:29804151.

ZACCHINO, S., 2001. Estratégias para a descoberta de novos agentes antifúngicos. In: R.A. YUNES, ed. Plantas medicinais sob a ótica da química medicinal moderna. Chapecó: Argos, pp. 435-479.

ZUPANČIČ, J., BABIČ, M.N. and GUNDE-CIMERMAN, N., 2018. High incidence of an emerging opportunistic pathogen Candida parapsilosis in water-related domestic environments. In: E.S. LORETO and J.S.M. TONDOLO, eds. Fungal infection. London: IntechOpen. 